\title{
Empowering scientific thinking skills through creative problem solving with scaffolding learning
}

\author{
Devi Ratnasari a,1,", Suciati a,2, Maridi a,3 \\ a Magister of Science Education, Faculty of Teacher Training and Education, Universitas Sebelas Maret, Jl. Insinyur Sutami No.36 A, Katingan Jebres, \\ Surakarta, Central Java, 57126, Indonesia \\ ${ }^{1}$ devi_ratnasari1392@yahoo.com*; ${ }^{2}$ suciati.sudarisman@yahoo.com; ${ }^{3}$ maridi_uns@yahoo.co.id \\ * corresponding author
}

\begin{tabular}{|c|c|}
\hline ARTICLE INFO & ABSTRACT \\
\hline $\begin{array}{l}\text { Article history } \\
\text { Received November 28, } 2018 \\
\text { Revised February 23, 2019 } \\
\text { Accepted February 27, } 2019 \\
\text { Published February 28, } 2019 \\
\text { Keywords } \\
\text { Creative problem solving } \\
\text { Scaffolding learning } \\
\text { Scientific thinking skills }\end{array}$ & $\begin{array}{l}\text { Scientific thinking is a crucial skill for students in facing } 21 \text { st-century challenges. The } \\
\text { aim of this study was to analyze the effect of Creative Problem Solving (CPS) with } \\
\text { scaffolding learning implementation on students' thinking skills. The study employed } \\
\text { pre-experimental design in which the sample was } 96 \text { of population was } 270 \text { students. } \\
\text { The sampling technique used was cluster random sampling. The data obtained from the } \\
\text { test instrument constructed from four aspects observed. The data was analyzed using } \\
\text { dependent t-test. The results showed that there was an influence of the CPS with } \\
\text { scaffolding on students' scientific thinking skills. Thus, CPS with scaffolding learning } \\
\text { effectively empowered the students' scientific thinking skills. } \\
\text { This is an open access article under the CC-BY-SA license }\end{array}$ \\
\hline \multicolumn{2}{|c|}{$\begin{array}{l}\text { How to cite: Ratnasari, D., Suciati, S., \& Maridi, M. (2019). Empowering scientific thinking skills through creative problem solving } \\
\text { with scaffolding learning. JPBI (Jurnal Pendidikan Biologi Indonesia), } 5 \text { (1), 61-68. doi: https://doi.org/10.22219/jpbi. } \\
\text { v5i1.7135 }\end{array}$} \\
\hline
\end{tabular}

\section{INTRODUCTION}

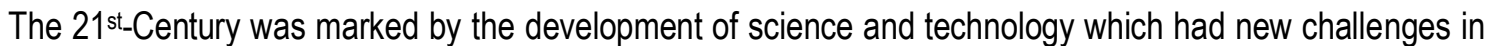
the education field (Ekanem, Ekanem, Ejue, \& Amimi, 2010; Ogunseemi, 2015). According to Griffin, McGaw, \& Care (2012) students are required to have four important skills, namely way of thinking, the way of working, the tool of working, and living in the world. To meet these demands, students need higher-order thinking skills in associating the learning process (Caleb Chidozie Chinedu, Olabiyi, \& Kamin, 2015; Jerome, Lee, \& Ting, 2017). McFarlane (2013) states that students need a learning process and higher-order thinking skills that can explain the process of science such as making new discoveries by utilizing problems in the surrounding environment. One of higher-order thinking that should be possessed by students is scientific thinking skills.

Someone who could think scientifically is a person who has the ability to receive, process and evaluate information in accordance with the context of science (Bao et al., 2009). According to Kuhn (2010) the ability to think scientifically has four aspects, namely: (1) inquiry, the discovery step that involves the scientific method in the process which includes the steps of finding the main idea of the problem, formulating a problem, designing a hypothesis and finding a solution to the problem; (2) analysis, the process of confirming data obtained with existing theories so as to obtain the truth; (3) inference, the process of confirming the truth between the theories used to find the idea of completion with the data obtained so that conclusions are obtained 
accordingly; and (4) argumentation, the process of students conveying their findings and also utilizing findings in daily life.

Scientific thinking skills are the basic competency of problem-solving skills (Bao et al., 2009; McComas, 2014). Scientific thinking skills also play a role in the development of higher-order thinking skills. Thus, empowering high-order thinking skills of students can be done by empowering their scientific skills. In addition, these skills also influence students' logical and systematic thinking (Jo \& Bednarz, 2014). Therefore, scientific thinking skills are skills that must be possessed by students.

Based on previous research that has been carried out, empowerment of scientific thinking skills has been done by some researchers. However, those researches were only limited to certain aspects. Research that empowers all aspects is still rarely found. Aspects that have been widely empowered in existing research are aspects of inquiry and analysis (Kuhn \& Dean, 2005). Whereas, the other research just focused on aspects of inference (Kuhn, 2010). In addition to aspects of the ability to think scientifically, another empowerment that has been done are using learning tools.

In Indonesia, some research that focused on scientific thinking skills has also been conducted. The research conducted by Wijayanti (2014) investigated the influence of authentic assessment on the learningbased scientific approach. In addition, there is also researcher that develop textbooks and learning media (Fitriyanti, Hidayat, \& Munzil, 2017). The other researchers studying the effect of discovery models on scientific thinking skills (Anas, 2016). In his research, Anas informed that the scientific approach-based learning model can empower students' scientific thinking abilities. The result is supported by Thitima \& Sumalee (2012) who concluded that the model-based scientific approach was also able to effectively empower the ability to think scientifically.

Based on some previous studies, the implementation of appropriate learning model has the potency to empower students' scientific thinking skills. The scientific approach-based learning model is effective to empower students' scientific thinking skills. The scientific-based learning model is able to facilitate all aspects of the ability to think scientifically (Thitima \& Sumalee, 2012). One learning model based on the scientific approach is Creative Problem Solving (CPS) learning model.

The CPS learning model is a learning model that systematically refers to students' creativity in solving problems (Putra, Widodo, Jatmiko, \& Mundilarto, 2018; Sari, Ikhsan, \& Abidin, 2018; Vidal, 2010; Zidulka, 2017). The model is in line with the scientific approach where students must act as scientists to find their own knowledge. Science learning is always referring to discoveries that begin with a question about the problems that arise (Bevins \& Price, 2016; Hu, Xiaohui, \& Shieh, 2017; Marra, Jonassen, \& Palmer, 2014). This concept is the basis of the CPS learning model (Lederman, Lederman, \& Antink, 2013).

The syntax of the CPS learning model according to Osborn-Parnes (Ayers, 1989) is (1) Mess Finding: students are given problems and students are required to observe existing problems and find the object of problems that must be resolved; (2) Fact Finding: students will find initial data from object problems that will be resolved so that later students are able to formulate the problems to be solved; (3) Problem Finding: students compiling the formulation of the problem to be solved; (4) Idea Finding: students discover the possible problemsolving ideas; (5) Solution Finding: students accommodate all the ideas of settlement ideas that have been proposed, then selects which ideas are suitable for problem-solving based on existing theories; (6) Action Finding: students testing the solution ideas that have been proposed to obtain data actually so students are able to do it confirm the data with the existing theory whether the solution formed at the beginning is in accordance with the problems that arise.

Each step of the CPS model is generally an aspect of the scientific approach. Students who do not understand the problem solving by using a scientific approach will certainly experience difficulties in applying this learning model as a whole (Zaim, 2017). Therefore, students need to get help before carrying out the learning process using the CPS learning model. Possible assistance that could be carried out by the teacher to overcome this condition is introduced scaffolding during the learning process.

Through scaffolding, teacher assisting gradually to students who are referring to the difficulties faced by students during the learning process (Belland, 2017; Chairani, 2015; Malik, 2017; Murtagh \& Webster, 2010). Scaffolding helps students in the process of finding and solving problems in a guided manner. Guidance given will be gradually reduced when students have been able to solve their own problems. Scaffolding teaches students to interact with teachers and peers in the learning process. According to Vygotsky, the interaction of interpersonal (social), cultural-historical and individual factors is the main center of human development. Interactions that occur between students and the surrounding environment will stimulate the development process and will encourage students' cognitive development in solving problems.

Scaffolding has three stages, namely; (1) environmental provisions; (2) explaining, reviewing and restructuring; and (3) developing conceptual thinking (Walshaw, 2016). Scaffolding must be done because it can help students recall the basic knowledge that students have and help stimulate new knowledge with the 
help of the teacher. In addition, scaffolding is also able to build student motivation in learning and reduce students' insecurity when unable to solve problems in the learning process.

The application of CPS in the learning process, as well as educational research in Indonesia, is still rarely found. Some researchers have conducted this kind of study. Some of these studies included researchers who examined the effect of CPS on metacognitive skills (Effendi, 2017) and mathematical problem-solving skills (Zulyadaini, 2017). Research that examines the effect of applying this model on scientific thinking skills is still difficult to find. Therefore, the purpose of the study was to analyze the effect of the CPS learning model along with scaffolding on the ability to think scientifically in students.

\section{METHOD}

The pre-experimental research was chosen as research designs in this study. The independent variable in this study was the CPS learning model accompanied by scaffolding. The dependent variable in this study was the ability of students to think scientifically. The research was carried out in State High Schools in Special Province of Yogyakarta. The population is 270 students whereas the research sample was 9611 th grade students of Yogyakarta $8 \mathrm{High}$ School. The sample was taken by cluster sampling technique. Since the number of students and the proportion of students in each school was different, before taking samples using cluster sampling, it is necessary to use stratified random sampling.

The study was conducted in the second semester of the 2017/2018 school year in 11th grade MIPA with the topic of the Digestive System. The research phase was divided into three stages, namely the stages of preparation, data collection and data processing. The preparation phase includes the preparation stages of research instruments which include learning instruments that use the CPS learning model along with scaffolding, learning outcomes measurement instruments and instruments for measuring scientific thinking abilities.

The data collection phase includes the implementation stage of the learning process using the CPS learning model along with scaffolding followed by measurement of the ability to think scientifically. The syntax of the CPS learning model along with scaffolding is presented in Table 1.

Table 1. Syntax of CPS with scaffolding

\begin{tabular}{llll}
\hline Syntax of CPS (Osborn-Parnes) & \multicolumn{1}{c}{ Syntax of Scaffolding } & \multicolumn{2}{l}{ Syntac of CPS With Scaffolding } \\
\hline & 1. Environmental Provisions & 1. Environmental Provisions \\
1. Mess Finding & & 2. Mess Finding \\
2. Fact Finding & & 3. Fact Finding \\
3. Problem Finding & 2. Explaining, Reviewing and & 4. Problem Finding \\
& & Sestructuring & Explaining, Reviewing and \\
& & 6. Idea Finding \\
4. Idea Finding & & 7. Solution Finding \\
5. Solution Finding & 3. Developing Conceptual Thinking & 8. Developing Conceptual Thinking \\
6. Action Finding & & 9. Action Finding \\
\hline
\end{tabular}

Table 2. Aspects of scientific thinking skills

\begin{tabular}{lll}
\hline \multicolumn{1}{c}{ Aspects } & \multicolumn{1}{c}{ Indicator } \\
\hline 1. Inquiry & a. Formulating Objectives. \\
& b. Identify the results of observations of issues / phenomena. \\
& c. Explain the definition of the problem statement. \\
& d. Formulate problems based on issues / phenomena. \\
& e. Make a hypothesis. \\
& f. Explain the definition of a hypothesis. \\
\hline 2. Analysis & a. Reasoning on the results of the literature review. \\
& b. Designing experimental designs. \\
& c. Presenting experimental data. \\
\hline 3. Inference & d. Expressing concepts or theories from observations. \\
& a. Make conclusions. \\
\hline 4. Argument & b. Match conclusions with hypotheses. \\
\hline
\end{tabular}


Measuring the ability of scientific thinking was done by giving multiple choice test questions arranged based on aspects of the ability to think scientifically according to (Kuhn \& Dean, 2005). Tests include the pretest and posttest tests. Pretest was given before the learning process in the Digestive System topic starts and the posttest was given after the learning process is complete. The questions amounted to 20 multiple choice questions which were previously validated by two experts which included construct validation and content validation. The scientific thinking ability test indicators are presented in Table 2 . Then, data from the research results were analyzed using inferential statistical analysis techniques. The statistical test used was the dependent t-test, which previously performed the normality test using the Kolmogorov-Smirnov test and homogeneity test using the Levene's test with the help of SPSS 21.

\section{RESULTS AND DISCUSSION}

CPS is one of the problem-based learning model. Through the incorporation of the CPS syntax with the scaffolding step, it produces a new learning syntax that may able to empower students' thinking abilities. In this study, the positive impact of CPS learning model with scaffolding was studied and scientific thinking skills, as well as learning outcomes, were chosen as a learning parameter. The frequency distribution of scientific thinking skills score tests and learning outcomes score test are presented in Table 3 and Table 4, respectively. Based on Table 3, the interval score between 79 and 82 is the common score obtained by students. On the other hand, based on Table 4, the average value of the highest student learning outcomes is in the range $88-91$ which is equal to $41.67 \%$.

Table 3. Frequency distribution of scientific thinking skills data

\begin{tabular}{ccc}
\hline Interval & Frequency & Percentage (\%) \\
\hline $75-78$ & 25 & 26,04 \\
$79-82$ & 34 & 35,42 \\
$83-86$ & 26 & 27,08 \\
$87-90$ & 9 & 9,38 \\
$91-94$ & 0 & 0 \\
$95-98$ & 2 & 2,08 \\
Total & 96 & $100 \%$ \\
\hline
\end{tabular}

Furthermore, data on learning outcomes and scientific thinking abilities were analyzed using the dependent $\mathrm{t}$-test. The results of the analysis data are presented in Table 5 . Based on the results of data analysis, it was obtained that there was a significant influence of CPS learning model and scaffolding on the ability to think scientifically $(p<.005)$. However, the difference result was obtained in learning outcomes parameters $(p=$ $.092)$.

Table 4. Distribution of frequency of learning outcomes score

\begin{tabular}{ccc}
\hline Interval & Frequency & Percentage (\%) \\
\hline $80-83$ & 9 & 9,37 \\
$84-87$ & 18 & 18,76 \\
$88-91$ & 40 & 41,67 \\
$92-95$ & 24 & 25 \\
$96-99$ & 5 & 5,2 \\
\hline Total & 96 & 100 \\
\hline
\end{tabular}

Table 5. Result of the data analysis

\begin{tabular}{ccc}
\hline Parameters & t-value & $p$-value \\
\hline Scientific thinking skills & 14.502 & $<.005$ \\
Learning outcomes & 1.700 & .092 \\
\hline
\end{tabular}

The CPS learning model could accommodate students to train their ability in solving the problem. Through implementing this learning model, the students are habituating to solve the problem creatively (Putra, Widodo, Jatmiko, \& Mundilarto, 2018; Sari, Ikhsan, \& Abidin, 2018; Vidal, 2010; Zidulka, 2017). This information is in line with John Dewey's theory. In theory, problem-solving is explained as an active thinking process based on the thought process towards definitive conclusions. In addition, it is in line with Bruner's constructivism view, which considers that students will give better results if they are facilitated to seeking knowledge and experience actively and independently. 
However, the application of the CPS learning model has disadvantages. One such weakness is the difficulty of students in carrying out problem-solving activities. Therefore, scaffolding activities carried out by teachers in this study are expected to minimize these problems. Scaffolding activity was chosen as treatment in this study due to some references informed that this activity could assisting students during facing difficulties in learning process (Belland, 2017; Chairani, 2015; Malik, 2017; Murtagh \& Webster, 2010). Moreover, Chairani (2015) states that scaffolding is an effective method used to minimize student learning difficulties in problem-solving. This statement is in line with Samana (2013) who stated that scaffolding is not only effective for use by teachers but students are also able to do scaffolding among small groups between students, so as to help construct knowledge between students. In this study, scaffolding was indicated could help students overcome the difficulties during do the problem-solving activities.

CPS learning model with scaffolding is a learning model that combines the syntax of both where it is intended to produce a learning model that can empower all aspects of students' scientific thinking abilities. Scaffolding incorporated into the learning model aims to reduce the lack of the CPS learning model to bridge students in connecting the actual and potential zones of students. In accordance with the main concept in Vygotsky's learning theory (Shabani, 2016; Shabani, Khatib, \& Ebadi, 2010), Zone of Proximal Development (ZPD), there are various difficulties students may experience towards their potential zones, including 1) when solving problems students have limited working memory; 2) students' difficulties in carrying out analysis in solving problems; 3) the initial knowledge possessed by students is not comprehensive and is not well integrated into the subject matter; 4) students' difficulties in recalling knowledge that has long been obtained. According to van de Pol, Volman, and Beishuizen, (2010) and van de Pol, Volman, Oort, and Beishuizen (2015), various difficulties will be reduced by using the application of scaffolding in the learning process. This is in accordance with the results of the study that through the learning process with the CPS model accompanied by scaffolding higher learning outcomes were obtained.

The positive impact of the application of the scientific approach based learning model as in this study is in line with the report from Anas (2016). Anas concluded that the selection of learning models that accommodate aspects of the scientific approach can improve students' scientific thinking skills. The learning model chosen in his research is the discovery learning model, while in this study using the CPS model accompanied by scaffolding. In the case of CPS, the learning model can facilitate student in learning biological content through a scientific approach. The student will be habituating with some scientific process, such as observing, asking, reasoning, analyzing and communicating. The positive results of this study are also in line with various previous studies which also examined the positive impact of CPS learning models implementation. Some of these studies reported that the application of CPS was able to increase student interest (Yin, 2015), learning outcomes (Lu \& Lin, 2017) and students' academic achievement (Putra et al., 2018).

However, although the CPS learning model influences students' scientific thinking abilities, this treatment did not significantly influence student learning outcomes. This result can be caused by some condition, both internal and external factors. The internal factors of students include students' readiness in receiving learning. When the learning schedule is in the afternoon students tend to be lazier and already look tired to follow the learning process. In contrast to students who get morning lesson schedules, students look more enthusiastic and enthusiastic in following the learning process. External factors of students include the environment and learning devices. A conducive environment is also able to influence how students can receive learning. This results in the acquisition of an insignificant score on the analysis of learning outcomes.

\section{CONCLUSION}

The conclusion of the study stated that the CPS learning model with scaffolding had a significant effect on students' scientific thinking abilities. The syntax of the CPS learning model is combined with the scaffolding step so that it produces a learning syntax that can accommodate aspects of the scientific approach that can empower students' scientific thinking abilities.

The application of the CPS learning model with scaffolding is expected to be a solution in empowering students' scientific thinking abilities. The CPS learning model accompanied by scaffolding that contains a combination of syntax can accommodate aspects of students 'scientific thinking abilities so that it is easier for teachers to train or empower students' scientific thinking skills. The learning process using the CPS with scaffolding is very complicated so that further research requires careful preparation. In addition, careful instrument validation is needed so that valid data is obtained. 


\section{REFERENCES}

Anas, N. (2016). Analisis kemampuan berpikir ilmiah (scientific thinking) siswa SD Tekad Mulia. Nizhamiyah, 4(1), 2016. Retrieved from http://jurnaltarbiyah.uinsu.ac.id/index.php/nizhamiyah/article/download/25/23

Ayers, S. J. (1989). Creative problem solving in the classroom. Lubbock. Retrieved from https://files.eric.ed. gov/fulltext/ED317446.pdf

Bao, L., Cai, T., Koenig, K., Fang, K., Han, J., Wang, J., ... Wu, N. (2009). Learning and scientific reasoning. Science, 323(5914), 586-587. doi: https://doi.org/10.1126/science.1167740

Belland, B. R. (2017). Instructional scaffolding: Foundations and evolving definition. Instructional Scaffolding in STEM Education: Strategies and Efficacy Evidence. Cham: Springer International Publishing. doi: https://doi.org/10.1007/978-3-319-02565-0

Bevins, S., \& Price, G. (2016). Reconceptualising inquiry in science education. International Journal of Science Education, 38(1), 17-29. doi: https://doi.org/10.1080/09500693.2015.1124300

Caleb Chidozie Chinedu, Olabiyi, O. S., \& Kamin, Y. Bin. (2015). Strategies for improving higher order thinking skills in teaching and learning of design and technology education. Journal of Techniqal Education and Training, 7(2), 35-43. Retrieved from http://penerbit.uthm.edu.my/ojs/index.php/JTET/ article/view/1081/795

Chairani, Z. (2015). Scaffolding dalam pembelajaran matematika. Math Didactic: Jurnal Pendidikan Matematika, 1(1), 39-44. Retrieved from https://media.neliti.com/media/publications/176909-ID-scaffol ding-dalam-pembelajaran-matematik.pdf

Effendi, A. (2017). Implementation of creative problem solving model to improve the high school student's metacognitive. In Journal of Physics: Conference Series (Vol. 812, p. 012065). doi: https://doi.org/10. 1088/1742-6596/812/1/012065

Ekanem, S. A., Ekanem, R. S., Ejue, J. B., \& Amimi, P. B. (2010). Science and technology research for sustainable development in Africa: The imperative of education. An International Multi-Disciplinary Journal, 4(3b), 71-89. Retrieved from https://www.ajol.info/index.php/afrrev/article/download/60227/ 48474

Fitriyanti, I., Hidayat, A., \& Munzil. (2017). Pengembangan perangkat pembelajaran IPA untuk meningkatkan kemampuan berpikir tingkat tinggi dan penalaran ilmiah siswa sekolah menengah pertama. Jurnal Pembelajaran Sains, 1(1), 27-34. Retrieved from http://journal2.um.ac.id/index.php/jpsi/article/down load/651/791

Griffin, P., McGaw, B., \& Care, E. (2012). Assessment and teaching of 21st century skills. Dordrecht: Springer Netherlands. doi: https://doi.org/10.1007/978-94-007-2324-5

Hu, R., Xiaohui, S., \& Shieh, C. J. (2017). A study on the application of creative problem solving teaching to statistics teaching. Eurasia Journal of Mathematics, Science and Technology Education, 13(7), 31393149. doi: https://doi.org/10.12973/eurasia.2017.00708a

Jerome, C., Lee, J. A.-C., \& Ting, S.-H. (2017). What students really need: instructional strategies that enhance higher order thinking skills (HOTS) among unimas undergraduates. International Journal of Business and Society, 18(4), 661-668. Retrieved from http://www.ijbs.unimas.my/images/repository/ pdf/Vol18-s4-paper2.pdf

Jo, I., \& Bednarz, S. W. (2014). Developing pre-service teachers' pedagogical content knowledge for teaching spatial thinking through geography. Journal of Geography in Higher Education, 38(2), 301-313. doi: https://doi.org/10.1080/03098265.2014.911828

Kuhn, D. (2010). What is scientific thinking and how does it develop? In The Wiley-Blackwell Handbook of Childhood Cognitive Development (pp. 497-523). Oxford, UK: Wiley-Blackwell. doi: https://doi.org/10. 1002/9781444325485.ch19

Kuhn, D., \& Dean, D. (2005). Is developing scientific thinking all about learning to control variables? Psychological Science, 16(11), 866-870. doi: https://doi.org/10.1111/j.1467-9280.2005.01628.x

Lederman, N. G., Lederman, J. S., \& Antink, A. (2013). Nature of science and scientific inquiry as contexts for the learning of science and achievement of scientific literacy. International Journal of Education in Mathematics Science and Technology, 1(3), 138-147. Retrieved from https://files.eric.ed.gov/fulltext/ED 543992.pdf

Lu, H.-K., \& Lin, P.-C. (2017). A study of the impact of collaborative problem-solving strategies on students' performance of simulation-based learning - A case of network basic concepts course. International 
Journal of Information and Education Technology, 7(5), 361-366. doi: https://doi.org/10.18178/ijiet. 2017.7.5.895

Malik, S. A. (2017). Revisiting and re-representing scaffolding: The two gradient model. Cogent Education, 4(1), 1-13. doi: https://doi.org/10.1080/2331186X.2017.1331533

Marra, R. M., Jonassen, D. H., \& Palmer, B. (2014). Why problem-based learning works: Theoretical foundations. Journal on Excellence in College Teaching, 25, 221-238. doi: https://doi.org/10.1111/j. 1600-0722.2010.00745.x

McComas, W. F. (2014). Scientific thinking skills. In W. F. McComas (Ed.), The Language of Science Education (pp. 96-96). Rotterdam: SensePublishers. doi: https://doi.org/10.1007/978-94-6209-497-0_86

McFarlane, D. A. (2013). Understanding the challenges of science education in the 21st century: New opportunities for scientific literacy. International Letters of Social and Humanistic Sciences, 4, 35-44. doi: https://doi.org/10.18052/www.scipress.com/LSHS.4.35

Murtagh, L. \&, \& Webster, M. (2010). Summary for Policymakers. In Intergovernmental Panel on Climate Change (Ed.), Climate Change 2013 - The Physical Science Basis (Vol. 1, pp. 1-30). Cambridge: Cambridge University Press. doi: https://doi.org/10.1017/CBO9781107415324.004

Ogunseemi, O. E. (2015). Science and technology in Africa for the twenty first century: Perspectives for change. European Scientific Journal, 307-313. Retrieved from https://eujournal.org/index.php/esj/ article/download/6540/6265

Putra, M. I. S., Widodo, W., Jatmiko, B., \& Mundilarto. (2018). The deveopment of science CPS (Collaborative Problem Solving) learning model to improve future islamic elementary school teachers' collaborative problem-solving skills and science literacy. Unnes Science Education Journal, 7(1), 35-49. doi: https:/l doi.org/10.15294/usej.v7i1.19536

Samana, W. (2013). Teacher's and students' scaffolding in an EFL classroom. Academic Journal of Interdisciplinary Studies, 2(8), 338-343. doi: https://doi.org/10.5901/ajis.2013.v2n8p338

Sari, D. M., Ikhsan, M., \& Abidin, Z. (2018). The development of learning instruments using the creative problem-solving learning model to improve students' creative thinking skills in mathematics. In Journal of Physics: Conference Series (Vol. 1088, p. 012018). doi: https://doi.org/10.1088/1742-6596/1088/ $1 / 012018$

Shabani, K. (2016). Applications of Vygotsky's sociocultural approach for teachers' professional development. Cogent Education, 3(1), 1-10. doi: https://doi.org/10.1080/2331186X.2016.1252177

Shabani, K., Khatib, M., \& Ebadi, S. (2010). Vygotsky's zone of proximal development: Instructional implications and teachers' professional development. English Language Teaching, 3(4), 237-248. doi: https://doi.org/10.5539/elt.v3n4p237

Thitima, G., \& Sumalee, C. (2012). Scientific thinking of the learners learning with the knowledge construction model enhancing scientific thinking. In Procedia - Social and Behavioral Sciences (Vol. 46, pp. 37713775). doi: https://doi.org/10.1016/j.sbspro.2012.06.144

Vidal, R. V. V. (2010). Creative problem solving: An applied university course. Pesquisa Operacional, 30(2), 405-426. doi: https://doi.org/10.1590/S0101-74382010000200009

van de Pol, J., Volman, M., \& Beishuizen, J. (2010). Scaffolding in teacher-student interaction: A decade of research. Educational Psychology Review, 22(3), 271-296. doi: https://doi.org/10.1007/s10648-0109127-6

van de Pol, J., Volman, M., Oort, F., \& Beishuizen, J. (2015). The effects of scaffolding in the classroom: Support contingency and student independent working time. Instructional Science, 43(5), 615-641. doi: https://doi.org/10.1007/s11251-015-9351-z

Walshaw, M. (2016). Lev Vygotsky. In E. de Freitas \& M. Walshaw (Eds.), Alternative Theoretical Frameworks for Mathematics Education Research (pp. 11-37). Cham: Springer International Publishing. doi: https:// doi.org/10.1007/978-3-319-33961-0_2

Wijayanti, A. (2014). Pengembangan autentic assesment berbasis proyek dengan pendekatan saintifik untuk meningkatkan keterampilan berpikir ilmiah mahasiswa. Jurnal Pendidikan IPA Indonesia, 3(2), 102-108. doi: https://doi.org/10.15294/jpii.v3i2.3107

Yin, K. Y. (2015). Collaborative problem solving promotes students' interest. Journal of Economics and Economic Education Research, 16(1), 158-167. Retrieved from https://www.alliedacademies.org/ articles/religious-participation-and-economic-recessions.pdf

Zaim, M. (2017). Implementing scientific approach to teach english at senior high school in Indonesia. Asian Social Science, 13(2), 33. doi: https://doi.org/10.5539/ass.v13n2p33 
Zidulka, A. D. (2017). Creative problem solving (CPS) in practice: A case study. University of Calgary. doi: https://doi.org/10.11575/PRISM/25483

Zulyadaini. (2017). Effects of creative problem solving learning model on mathematical problem solving skills of senior high school students. IOSR Journal of Research \& Method in Education, 7(3), 33-37. doi: https://doi.org/10.9790/7388-0703033337 